\title{
Содержание. Contents
}

\section{ЭКОНОМИКА, ПОЛИТИКА, СОЦИУМ И КУЛЬТУРА ECONOMICS, POLITICAL SCIENCE, SOCIETY AND CULTURE}

Задорин М.Ю., Минчук О.В. Этнополитика России в Арктической зоне: интеграция, региональная мультикультуральность, традиция

Maksim Yu. Zadorin, Oleg V. Minchuk The ethnopolitics of Russia in the Arctic zone: integration, regional multiculturality, and tradition

Зиланов В.К. Арктическое разграничение России и Норвегии: новые вызовы и сотрудничество Vyacheslav K. Zilanov Delimitation between Russia and Norway in the Arctic: new challenges and cooperation

Максимов А.М., Малинина К.О., Блынская Т.А., Балицкая С.М. Методологические и методические аспекты изучения социального самочувствия населения Арктической зоны Российской Федерации в контексте его ценностных ориентаций

Anton M. Maximov, Kristina O. Malinina, Tatyana A. Blynskaya, Svetlana M. Balitskaya Methodological and methodical aspects of studying the social well-being of the population of the Arctic zone of the Russian Federation in the context of its value orientation

Тодоров А.А. Правовой спор между Россией и США о Северном морском пути и похожий вопрос о Северо-западном морском пути

Andrey A. Todorov The Russia-USA legal dispute over the straits of the Northern Sea Route and similar case of the Northwest Passage

Фаузер В.В., Лыткина Т.С., Фаузер Г.Н. Государственные преференции для населения отдалённых и северных территорий России

Viktor V. Fauzer, Tatyana S. Lytkina, Galina N. Fauzer State preferences for the people in remote and northern territories of Russia

Эльгсаас И.М. Противодействие терроризму в российской Арктике: законодательство и ключевые субъекты

Ingvill M. Elgsaas Counterterrorism in the Russian Arctic: legal framework and central actors

\section{ОБЗОРЫ И СООБЩЕНИЯ. REVIEWS AND REPORTS}

Обоимов А.П. На берегу студёного моря, средь скал, лесов...

Alexander P. Oboimov On the shore of the icy sea, among the rocks, and forests...

Шубин С.И., Рогачев И.В. «Соседи на крыше Европы» укрепляют побратимские связи

Sergey I. Shubin, Ivan V. Rogachev "The neighbors on the roof of Europe" strengthen friendly relations

\section{PE3ЮME. SUMMARY}

Авторы, названия, аннотации, ключевые слова / Authors, titles, abstracts, and keywords

Редакционный совет журнала «Арктика и Север» / Editorial board of "Arctic and North" journal 